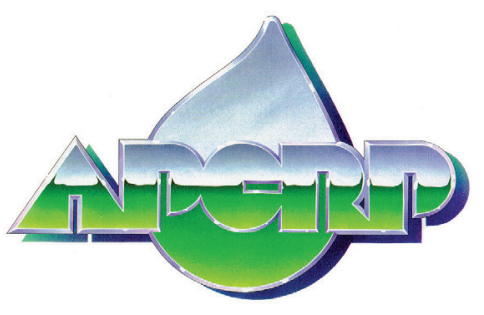

ERDC/TN APCRP CC-24

September 2021

\title{
Efficacy of Florpyrauxifen-benzyl for Eurasian Watermilfoil Control and Nontarget Illinois Pondweed, Elodea, and Coontail Response
}

by Christopher R. Mudge, Bradley T. Sartain, Benjamin P. Sperry, and Kurt D. Getsinger

PURPOSE: This research evaluated low concentrations and short exposure times of the recently registered aquatic herbicide florpyrauxifen-benzyl (4-amino-3-chloro-6-(4-chloro-2-fluoro-3methoxyphenyl)-5-fluoro-pyridine-2-benzyl ester) on the target plant Eurasian watermilfoil (Myriophyllum spicatum L., hereafter referred to as EWM) as well as selectivity towards the nontarget submersed species Illinois pondweed (Potamogeton illinoensis Morong), elodea (Elodea canadensis Michx.), and coontail (Ceratophyllum demersum L.)

BACKGROUND: Prior to 2018, only 14 herbicides with eight modes of action comprised the entire portfolio of the US Environmental Protection Agency's (USEPA) registered aquatic herbicides (Netherland and Jones 2012; University of Florida 2018). Recently, the arylpicolinate herbicide florpyrauxifen-benzyl was registered for use in aquatic sites in the United States (University of Florida 2018). Initial small-scale research reported florpyrauxifen-benzyl effectively controlled dioecious hydrilla (Hydrilla verticillate L.f. Royle), EWM, crested floating heart (Nymphoides cristata [Roxb.] Kuntze), megalodonta (Bidens beckii Torr. Ex Spreng), elodea, alligatorweed (Alternanthera philoxeroides [Mart.] Griseb.), fanwort (Cabomba caroliniana Gray), monoecious hydrilla, and parrot's-feather (M. aquaticum [Vell.] Verdc.) (Netherland and Richardson 2016; Richardson, Haug, Netherland 2016). However, these earlier published studies investigated florpyrauxifen-benzyl under static exposures, and the plants were tested using the Organization for Economic Cooperation and Development (OECD) method that uses apical shoots (that is, small fragments) to test sensitivity instead of actively growing, rooted plants. Recently, Beets, Heilman, and Netherland (2019) evaluated florpyrauxifen-benzyl against well-established and mature EWM, hybrid water milfoil (M. spicatum x M. sibiricum), and seven native submersed plants and found that concentrations of 3, 9, and $27 \mu \mathrm{g}{ }^{1}$ active ingredient (a.i.) $\mathrm{L}^{-1}$ at exposures of 6 and $24 \mathrm{hr}$ resulted in significant control of the invasive water milfoils and minimal negative impacts to the native species. Under field conditions, especially where herbicide exposures are limited due to partial lake treatments or applications to flowing water, target plant control may be limited. Therefore, this study conducted a growth chamber trial to evaluate the response of established EWM, as well as sensitivity of the non-target species Illinois pondweed, elodea, and coontail under shorter exposure times to florpyrauxifen-benzyl.

MATERIALS AND METHODS: A growth chamber experiment was conducted at the US Army Engineer Research and Development Center (ERDC) in Vicksburg, Mississippi, in 2019 to evaluate efficacy and selectively of florpyrauxifen-benzyl when applied subsurface to EWM, Illinois

\footnotetext{
1 . For a full list of the spelled-out forms of the units of measure used in this document, please refer to US Government Publishing Office Style Manual, 31st ed. (Washington, DC: US Government Publishing Office, 2016), 248-52, https://www.govinfo.gov/content/pkg/GPO-STYLEMANUAL-2016/pdf/GPO-STYLEMANUAL-2016.pdf. 
pondweed, elodea, and coontail. The experiment was conducted in a controlled-environment chamber equipped with $55 \mathrm{~L}$ glass aquaria, artificial lighting, and air bubblers designed for submersed plant culture (Netherland, Green, and Getsinger 1991; Mudge and Theel 2011). Conditions for the duration of experiments were air temperature, $22^{\circ} \mathrm{C}$; water $\mathrm{pH}, 7.5-8.0$; and a 14 hr: $10 \mathrm{hr}$ (light:dark) photoperiod. Plants were obtained from the following sources: EWM, ERDC ponds; elodea, ERDC stock cultures; Illinois pondweed, Lake Alfred (Lake Alfred, Florida); and coontail, Lake Swoope (Lake Alfred, Florida). On 1 March 2019, three EWM apical meristems (15 cm long), three elodea stem clippings (15 cm long), two coontail stem clippings (15 cm long), and two Illinois pondweed stem clippings $(25 \mathrm{~cm}$ long), were planted individually into $750 \mathrm{ml}$ plastic containers filled with 3:1 top soil:sand. This soil mix was amended with Osmocote (19-612, The Scotts Company, Marysville, Ohio) fertilizer ( $2 \mathrm{~g} \mathrm{~kg}^{-1}$ sediment) and saturated with water. A $1 \mathrm{~cm}$ layer of silica sand was added to the soil surface to reduce particulate matter and nutrient resuspension into the water column to prevent algal contamination. One container of each species was placed in each aquaria (that is, four species per aquaria) and filled with growth culture solution (Smart and Barko 1985).

On 2 April 2019, four weeks after planting, florpyrauxifen-benzyl was applied subsurface to aquaria at concentrations of 3,6 , or $9 \mu \mathrm{g}$ a.i. $\mathrm{L}^{-1}$. Following assigned exposure times of $0.5,1$, or $3 \mathrm{hr}$, aquaria were drained and refilled twice with reverse osmosis (RO) water and a third time with fresh growth culture solution (Smart and Barko 1985) to remove aqueous herbicide residues. Nontreated control (reference) aquaria were also used to compare plant growth in the absence of herbicide. Trials were set up in a completely randomized design and factorial arrangement of treatments with four replications. All viable shoot tissue was harvested six weeks after treatment (WAT, 17 May 2019), dried to a constant weight at $65^{\circ} \mathrm{C}$ and weighed. Biomass data were subjected to an analysis of variance (ANOVA) and means separated using Fisher's Protected LSD $(\alpha=0.05)$.

RESULTS AND DISCUSSION: All florpyrauxifen-benzyl treatments resulted in rapid injury to EWM and complete plant control (Figure 1). The higher herbicide concentrations and longer exposure treatments resulted in faster symptomology compared to the shorter concentration exposure time (CET) treatments. Injury symptoms including epinasty (twisting), swollen nodes, and chlorosis were observed within the first one to three days after treatment (DAT), which are similar to previous hybrid water milfoil growth chamber research studies conducted under similar CET treatment scenarios (Mudge et al. 2021). All florpyrauxifen-benzyl CET treatments resulted in 100\% reductions in EWM biomass by 5 WAT (Figure 1). Mudge et al. (2021) noted that this systemic herbicide applied at $3 \mu \mathrm{g}$ a.i. $\mathrm{L}^{-1}$ for $0.5 \mathrm{hr}$ reduced hybrid water milfoil biomass by $50 \%$, whereas the treatments consisting of 3 ( $4 \mathrm{hr}$ exposure), 6 ( $\geq 0.5 \mathrm{hr}$ exposure), and $9 \mu \mathrm{g}$ a.i. $\mathrm{L}^{-1}(\geq 0.5 \mathrm{hr}$ exposure) provided $\geq 95 \%$ plant control. These data also support previous findings that the Myriophyllum species (that is, hybrid water milfoil, parrot's-feather, and variable water milfoil) are highly sensitive to florpyrauxifen-benzyl at low doses and short exposure times (Netherland and Richardson 2016; Richardson, Haug, Netherland 2016; Mudge et al. 2021). 


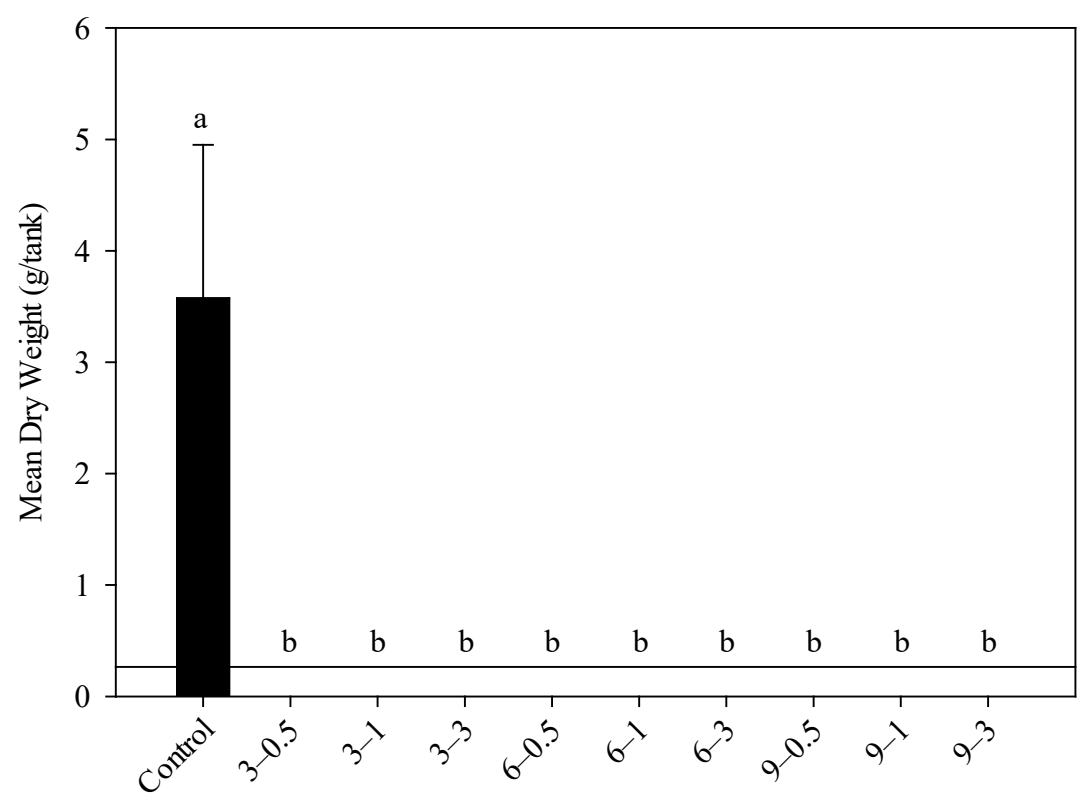

Herbicide Treatments

Figure 1. Eurasian watermilfoil mean dry weight ( \pm standard error) 6 weeks after treatment (WAT) of subsurface applications of florpyrauxifen-benzyl in a controlled-environment growth chamber. Numbers behind herbicide concentrations ( $\mu \mathrm{g}$ a.i. $\left.\mathrm{L}^{-1}\right)$ represent exposure time (hr). Horizontal line represents pretreatment biomass. Treatments with the same letter are not significant according to Fisher's Protected LSD ( $\alpha=0.05$, $n=4)$.

The nontarget aquatic species Illinois pondweed, elodea, and coontail were tolerant to the low concentrations and short exposures of florpyrauxifen-benzyl (Figures 2, 3, and 4). Coontail began to show injury symptoms 9 DAT that consisted of swollen nodes and bleached epinastic leaflets. By 24 DAT, coontail still showed minor visual injury symptoms; however, signs of recovery and new growth were present. Elodea and Illinois pondweed showed minimal to no injury throughout the duration of the trial. None of the florpyrauxifen-benzyl CET treatments resulted in biomass reductions of Illinois pondweed, elodea, and coontail (Figures 2, 3, and 4) when treated with the same CET treatments as EWM. In fact, five of the nine CET treatments resulted in an increase in elodea dry weight 6 WAT (Figure 3). Although not tested in the current trial, elodea data suggest that low concentrations of florpyrauxifen-benzyl may induce hormesis, which has been observed in other plant species exposed to low herbicide doses (Belz and Duke 2014; Cedergreen 2008). Similarly, elodea was not sensitive to florpyrauxifen-benzyl at concentrations of 3, 6, and $9 \mu \mathrm{g}$ a.i. $\mathrm{L}^{-1}$ when plants were exposed for 0.5 to $4 \mathrm{hr}$ in a previous growth chamber trial (Mudge et al. 2021). These data along with previous research (Netherland and Richardson 2016; Richardson, Haug, and Netherland 2016; Mudge et al. 2021), indicate that Myriophyllum species can be selectively controlled with lower herbicide concentrations using florpyrauxifen-benzyl than the previously utilized auxin herbicides 2,4-D and triclopyr that require concentrations $\geq 270 \mu \mathrm{g}$ acid equivalent (a.e.) $\mathrm{L}^{-1}$ to reduce shoot biomass $95-100 \%$ (Poovey et al. 2007). 


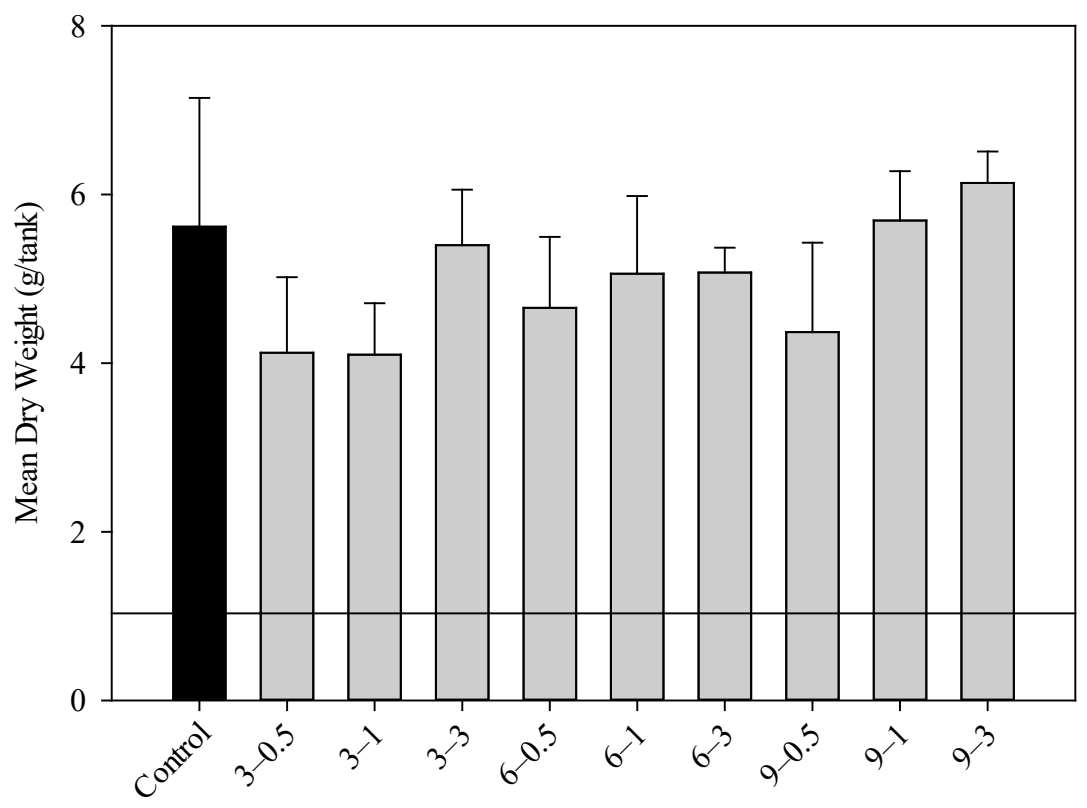

Herbicide Treatments

Figure 2. Illinois pondweed mean dry weight ( \pm standard error) 6 WAT of subsurface applications of florpyrauxifen-benzyl in a controlled-environment growth chamber. Numbers behind herbicide concentrations $\left(\mu \mathrm{g}\right.$ a.i. $\left.\mathrm{L}^{-1}\right)$ represent exposure time (hr). Horizontal line represents pretreatment biomass. There were no significant differences among treatments. 


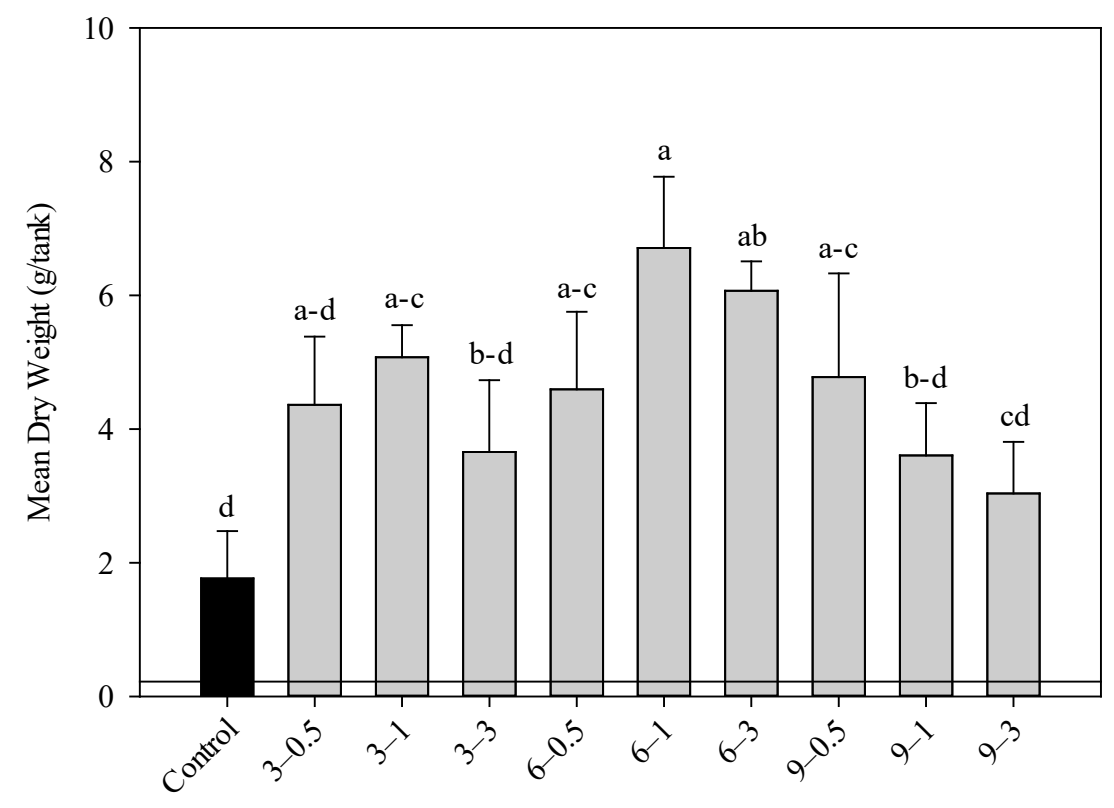

Herbicide Treatments

Figure 3. Elodea mean dry weight ( \pm standard error) 6 WAT of subsurface applications of florpyrauxifen-benzyl in a controlled-environment growth chamber. Numbers behind herbicide concentrations $\left(\mu \mathrm{g}\right.$ a.i. $\left.\mathrm{L}^{-1}\right)$ represent exposure time (hr). Horizontal line represents pretreatment biomass. There were no significant differences among treatments. 


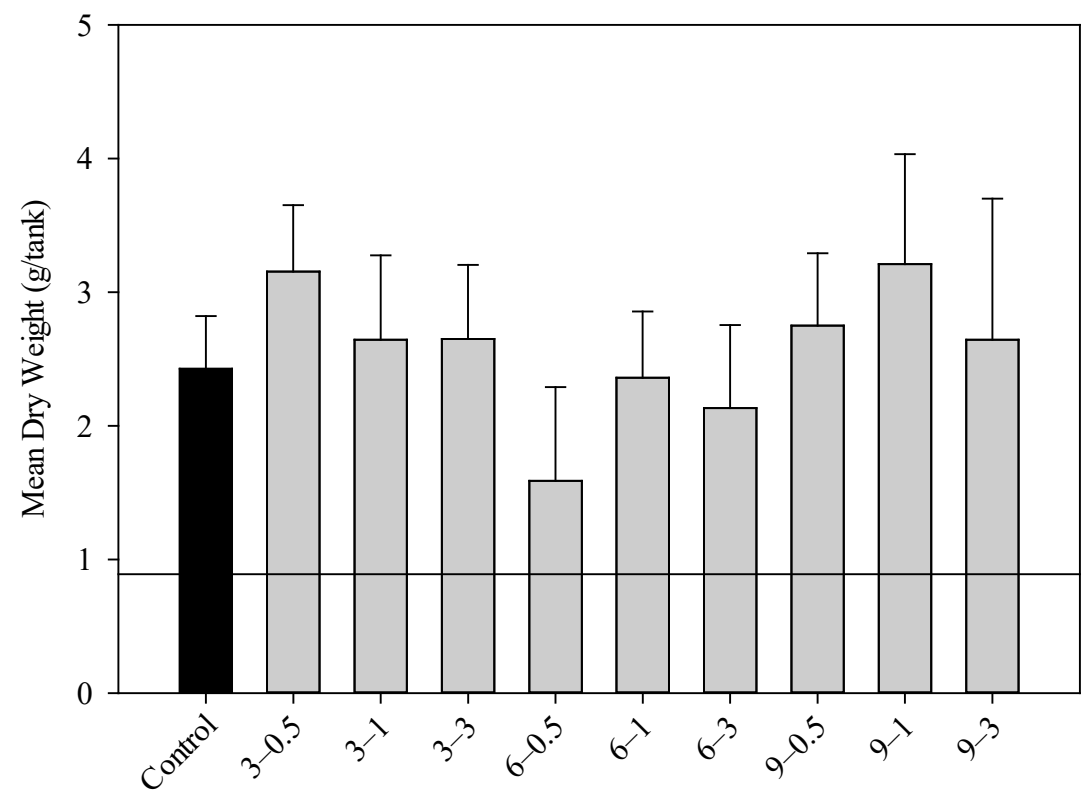

Herbicide Treatments

Figure 4. Coontail mean dry weight ( \pm standard error) 6 WAT of subsurface applications of florpyrauxifen-benzyl in a controlled-environment growth chamber. Numbers behind herbicide concentrations $\left(\mu \mathrm{g}\right.$ a.i. $\left.\mathrm{L}^{-1}\right)$ represent exposure time (hr). Horizontal line represents pretreatment biomass. There were no significant differences among treatments.

ACKNOWLEDGMENTS: The authors would like to thank Jan Freedman, William Prevost, Dr. Mark Heilman, and Dean Jones for technical assistance during these experiments. This research was sponsored by the US Army Engineer Research and Development Center Aquatic Plant Control Research Program.

\section{REFERENCES}

Beets, J., M. Heilman, and M. D. Netherland. 2019. "Large-scale mesocosm evaluation florpyrauxifen benzyl, a novel arylpicolinate herbicide on Eurasian and hybrid watermilfoil and seven native submersed plants." Journal of Aquatic Plant Management 57:49-55. http://www.apms.org/wp/wp-content/uploads/japm-57-02-49-1.pdf.

Belz, R. G., and S. O. Duke. 2014. "Herbicides and plant hormesis." Pest Management Science 70(5):698-707. https://doi.org/10.1002/ps.3726.

Cedergreen, N. 2008. "Herbicides can stimulate plant growth." Weed Research 48(5):429-438. https://doi.org/10.1111/j.1365-3180.2008.00646.x.

Mudge, C. R., B. T. Sartain, K. D. Getsinger, D. Michael, and M. D. Netherland. 2021. Efficacy of florpyrauxifenbenzyl on dioecious hydrilla and hybrid watermilfoil - concentration and exposure time requirements. ERDC/EL TR-21-8. Vicksburg, MS: U.S. Army Engineer Research and Development Center.

Mudge, C. R., and H. J. Theel. 2011. "Endothall concentration exposure time evaluation against Eurasian watermilfoil at a lower water temperature." APCRP Technical Note Collections. ERDC/TN APCRP-CC-15. Vicksburg, MS: U.S. Army Engineer Research and Development Center. 
Netherland, M. D., and R. J. Richardson. 2016. "Evaluating sensitivity of five aquatic plants to a novel arylpicolinate herbicide utilizing an Organization for Economic Cooperation and Development protocol." Weed Science 64(1):181-190. https://doi.org/10.1614/WS-D-15-00092.1

Netherland, M. D., and K. D. Jones. 2012. "Registered herbicides and improving their efficacy on aquatic weeds." Aquatics 34(3):12-15.

Netherland, M. D., W. R. Green, and K. D. Getsinger. 1991. Endothall concentration and exposure time relationships for the control of Eurasian watermilfoil and hydrilla. Journal of AquaticPlant Management 29:61-67.

Poovey, A. G., J. G. Slade, and M. D. Netherland. 2007. "Susceptibility of Eurasian watermilfoil (Myriophyllum spicatum) and milfoil hybrid (M. spicatum x M. sibiricum) to triclopyr and 2,4-D amine." Journal of Aquatic Plant Management 45:111-115.

Richardson, R. J., E. J. Haug, and M. D. Netherland. 2016. "Response of seven aquatic plants to a new arylpicolinate herbicide". Journal of Aquatic Plant Management 54:26-31.

University of Florida. 2018. Plant management in Florida waters - An integrated approach. Background on the aquatic herbicides registered for use in Florida. https://plants-archive.ifas.ufl.edu/manage/control-methods/chemicalcontrol/details-about-the-aquatic-herbicides-used-in-florida/. Accessed 20 July 2021.

NOTE: The contents of this technical note are not to be used for advertising, publication, or promotional purposes. Citation of trade names does not constitute an official endorsement or approval of the use of such products. 